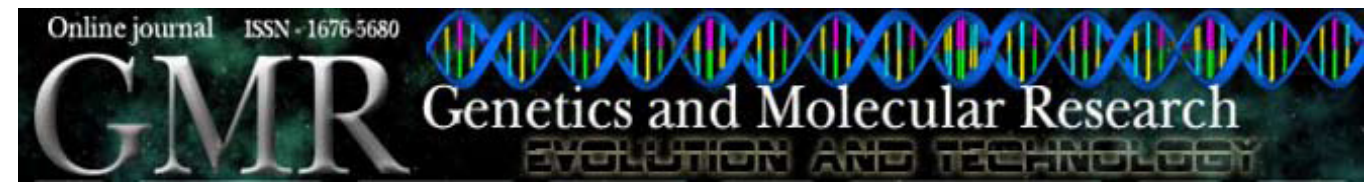

\title{
Characterization of mitochondrial genotypes in the foundation herd of the Canchim beef cattle breed
}

\author{
S.C. Méo ${ }^{1}$, C.R. Ferreira ${ }^{2}$, M.R. Chiaratti ${ }^{2}$, F.V. Meirelles $^{2}$, \\ L.C.A. Regitano ${ }^{1}$, M.M. Alencar ${ }^{1}$ and P.F. Barbosa ${ }^{1}$ \\ ${ }^{1}$ Embrapa Pecuária Sudeste, São Carlos, SP, Brasil \\ ${ }^{2}$ Departamento de Ciências Básicas, Faculdade de Zootecnia e \\ Engenharia de Alimentos, Universidade de São Paulo, \\ Pirassununga, SP, Brasil \\ Corresponding author: S.C. Méo \\ E-mail: simone@cppse.embrapa.br
}

Genet. Mol. Res. 8 (1): 261-267 (2009)

Received December 22, 2008

Accepted January 12, 2009

Published March 3, 2009

\begin{abstract}
The Canchim (5/8 Charolais $+3 / 8$ Zebu) beef cattle breed was developed at Southeast-Embrapa Cattle to take advantage of hybrid vigor and to combine the higher growth rate and beef quality of Charolais with tropical adaptations of Zebu. The development of three lineages (old, new, and crossbred) has increased its genetic basis. The genotypic origin (Bos taurus or Bos indicus) of the mitochondrial DNA (mtDNA) of the Canchim breed was unknown. We characterized the mtDNA genotype of this founder herd by allelespecific polymerase chain reaction. The 173 founder Zebu females (62 Indubrasil, 3 Guzerat, and 108 Nellore) and their 6749 offspring were identified. The frequency of $B$. indicus mtDNA ranged from 1.15 to $2.05 \%$ among the descendants $(\mathrm{N}=6404)$ of each maternal line with available DNA, and among animals that were alive $(\mathrm{N}=$ 689) in December 2007 among the three lineages. Though mtDNA characterization can be used to direct animal selection, the low frequency of $B$. indicus mtDNA impairs the evaluation of its effects on production traits in these animals. The high prevalence of $B$. taurus
\end{abstract}


mtDNA in Canchim proves that the founder Zebu females from the Indubrasil, Guzerat and Nellore breeds were obtained from crosses of Zebu sires with local B. taurus dams.

Key words: Allele-specific polymerase chain reaction; Bovine; Maternal inheritance; Mitochondrial DNA

\section{INTRODUCTION}

The Canchim beef cattle breed is a 5/8 Charolais $+3 / 8 \mathrm{Zebu}$ composite whose development started in the decade of 1940 at São Carlos Experimental Station, in São Carlos, SP, Brazil (currently named Southeast-Embrapa Cattle). Initially, rotational crossing between Charolais (Bos taurus) bulls and Zebu (B. indicus) cows (from Guzerat, Indubrasil, and Nellore breeds) was employed to take advantage of heterosis and to complement the traits that were superior in Charolais (higher growth rate and beef quality) and in Zebu cattle (tropical adaptation; Vianna et al., 1978).

Since the early 1950's, the Canchim breed has been maintained as a closed herd to constitute the old Canchim lineage. In order to increase its genetic basis, a second lineage was formed after 1986, breeding Charolais bulls to $1 / 2$ Canchim $+1 / 2$ Nellore cows, constituting a new lineage. After 1998, animals of the old and new lineages were reciprocally mated to produce the crossbred lineage (Barbosa, 2000).

In Brazil, the Canchim breed has been successfully employed for beef production, especially when mated to Zebu and Zebu-cross females, improving reproductive efficiency, maternal ability, and growth rate (Alencar, 1997). For that reason, the Canchim breed has also been the object of research with molecular and quantitative tools (Regitano et al., 1999; Machado et al., 2003; Pereira et al., 2005; Meirelles, 2007; Andrade et al., 2008). However, the origin of its cytoplasmic genome (mitochondrial DNA; mtDNA) is unknown.

The maternally inherited mtDNA contains $16,600 \mathrm{bp}$; it codes for 13 polypeptides that are part of the mitochondrial respiratory chain, along with 22 tRNA, and two rRNA (Larsson and Clayton, 1995). Polymorphisms in mtDNA may affect mitochondrial protein synthesis and possibly adaptation of cattle to different environments (Larsson and Clayton, 1995; Meirelles et al., 2001). A few mtDNA polymorphisms have been studied in cattle; they have been reported to influence animal production, reproduction, and carcass traits, including milk production (Schutz et al., 1994), milk fat content (Boettcher et al., 1996), longissimus area, fat deposition, marbling (Mannen et al., 1998, 2003), blastocyst production (Tamassia et al., 2004), and calving rate (Sutarno et al., 2002).

Most Brazilian Zebu females of the Nellore, Gyr, and Brahman breeds (Meirelles et al., 1999) and some of the females of the Guzerat breed (Paneto et al., 2008) were obtained by backcrossing native cows with Zebu bulls; therefore, they harbor mtDNA of B. taurus origin. However, there is no information regarding the mtDNA genotype origin of Indubrasil, the main breed employed to produce the old lineage of Canchim. Since the Canchim was formed from Zebu females of different breeds and at different times, our hypothesis was that the breed includes a variable composition of mtDNA. We examined the mtDNA genotype origin (B. taurus or B. indicus) of Canchim animals belonging to 
three lineages (old, new, and crossbred) of the Southeast-Embrapa Cattle herd.

\section{MATERIAL AND METHODS}

\section{Maternal line identification}

We examined the animals of the Southeast-Embrapa Cattle herd in São Carlos, SP, Brazil. All genealogical data of Canchim breed animals born until December 2007 were analyzed to identify the founder females of the herd and their offspring, i.e., to establish the maternal line. The live animals were also grouped into three lineages: old, new and crossbred. Two descendants of each maternal line (the eldest and the youngest animal with available DNA) were submitted to genetic evaluation for characterization of mtDNA origin as B. taurus or B. indicus. The results obtained from these two animals were used to infer the mtDNA genotype of the maternal line. In 11 cases, only one animal per maternal line was evaluated due to a lack of DNA. In exceptional cases (mtDNA genotype discordance between the two descendants or $B$. indicus mtDNA identification) another five animals were evaluated to confirm the results.

\section{Molecular characterization of mtDNA origin}

Total DNA extraction was performed according to Regitano (2001). Briefly, $5 \mathrm{~mL}$ blood was collected after jugular vein punction into vacuum tubes with $15 \%$ EDTA. Red blood cells were disintegrated in hemolysis buffer ( $10 \mathrm{mM}$ Tris, $5 \mathrm{mM} \mathrm{MgCl}$, and $10 \mathrm{mM}$ $\mathrm{NaCl}$ ) and centrifuged at $700 \mathrm{~g}$ for 10 min to obtain a clean pellet of white blood cells. These cells were incubated in lysis buffer $(10 \mathrm{mM}$ Tris, $100 \mathrm{mM} \mathrm{NaCl}, 10 \mathrm{mM}$ EDTA, $0.5 \% \mathrm{SDS}$, and $50 \mu \mathrm{g}$ proteinase $\mathrm{K}$ ) overnight at $55^{\circ} \mathrm{C}$, while shaking. Afterwards, saline protein precipitation (4.67 mM Tris, $0.47 \mathrm{mM}$ EDTA, and $2.67 \mathrm{M} \mathrm{NaCl}$ ) was run on ice for $10 \mathrm{~min}$, followed by centrifugation at $16,000 \mathrm{~g}$ for $15 \mathrm{~min}$. The supernatant was homogenized in cold absolute ethanol (1:2), centrifuged at $16,000 \mathrm{~g}$ for $15 \mathrm{~min}$, and the resulting pellet was washed in cold $70 \%$ ethanol, centrifuged at $16,000 \mathrm{~g}$ for $5 \mathrm{~min}$, and air dried. Then, the DNA was dissolved in TE ( $10 \mathrm{mM}$ Tris and $1 \mathrm{mM}$ EDTA) with $10 \mu \mathrm{g} / \mathrm{mL}$ RNase at $37^{\circ} \mathrm{C}$ for $1 \mathrm{~h}$, quantified with a spectrophotometer, and stored at $-20^{\circ} \mathrm{C}$.

The mtDNA genotype was characterized as B. taurus (GenBank AY526085) or B. indicus (GenBank AY126697) by amplification of a 366-bp fragment of mtDNA 16S (rRNA) gene, using allele-specific polymerase chain reaction (PCR). Two PCR amplifications were performed of each sample. Then, in two separate reactions, one of the two specific forward primers for $B$. taurus mtDNA (5'-CCAATGATAACATCTCAACTG-3') or $B$. indicus mtDNA (5'-CCAATGACAGCATCTCAATCA-3') and the unspecific reverse primer (5'-GAGCTATGATGGGTGCTAGG-3') were employed (Ferreira et al., 2007). The PCR mixture consisted of $1 \mathrm{X}$ PCR buffer, $0.2 \mu \mathrm{M}$ each primer (forward and reverse), $1.5 \mathrm{mM} \mathrm{MgCl}, 200 \mu \mathrm{M}$ each dNTP, $0.25 \mathrm{U}$ Taq DNA polymerase, and $40 \mathrm{ng}$ total DNA in a final volume of $12.5 \mu \mathrm{L}$. The PCR cycles were initiated by one denaturation step of $95^{\circ} \mathrm{C}$ for $2 \mathrm{~min}$, followed by 36 cycles of denaturation at $94^{\circ} \mathrm{C}$ for $45 \mathrm{~s}$, annealing at $58^{\circ} \mathrm{C}$ for $55 \mathrm{~s}$, and extension at $72^{\circ} \mathrm{C}$ for $120 \mathrm{~s}$, and then a final incubation step at $72^{\circ} \mathrm{C}$ for 5 min, in a Mastercycler Gradient (Eppendorf) thermocycler. 
The amplified fragments generated by PCR were submitted to horizontal electrophoresis on $1.5 \%$ agarose gel with $0.025 \mu \mathrm{g} / \mathrm{mL}$ ethidium bromide in $1 \mathrm{X}$ TBE buffer ( 8.9 $\mathrm{mM}$ Tris, $8.9 \mathrm{mM}$ boric acid, and $2.8 \mathrm{mM}$ EDTA). After that, the gel was observed under a UV transiluminator at $302 \mathrm{~nm}$. Genotypes were determined based on the amplified fragment (B. taurus or B. indicus mtDNA).

\section{RESULTS}

Genealogical evaluation allowed the identification of maternal lines of the Canchim breed of the Southeast-Embrapa Cattle herd data, which is composed of 6749 individuals. These animals were descendants of 173 females (62 Indubrasil, 3 Guzerat, and 108 Nellore; Table 1), each representing from 0.015 to $4.1 \%$ of the population.

\begin{tabular}{|c|c|c|c|c|c|c|c|c|c|c|}
\hline \multirow{2}{*}{$\begin{array}{l}\text { Founder female } \\
\text { breed }\end{array}$} & \multicolumn{2}{|c|}{ Total } & \multicolumn{4}{|c|}{ Available DNA } & \multicolumn{4}{|c|}{ Alive in December 2007} \\
\hline & $\mathrm{N}$ & Desc. & $\mathrm{N}$ & Desc. & $\begin{array}{c}\text { B. taurus } \\
\text { mtDNA N (\%) }\end{array}$ & $\begin{array}{l}\text { B. indicus } \\
\text { mtDNA N (\%) }\end{array}$ & $\mathrm{N}$ & Desc. & $\begin{array}{c}\text { B. taurus } \\
\text { mtDNA N (\%) }\end{array}$ & $\begin{array}{c}\text { B. indicus } \\
\text { mtDNA N (\%) }\end{array}$ \\
\hline Indubrasil & 62 & 4531 & 43 & 4295 & $4218(98.21 \%)$ & 77 (1.79\%) & 32 & 246 & $244(99.19 \%)$ & $2(0.81 \%)$ \\
\hline Guzerat & 3 & 125 & 1 & 92 & $92(100 \%)$ & $0(0.0 \%)$ & 0 & 0 & $0(0.0 \%)$ & $0(0.0 \%)$ \\
\hline Nellore & 108 & 294 & 100 & 2017 & $1963(97.32 \%)$ & $54(2.68 \%)$ & 75 & 443 & $433(97.74 \%)$ & $10(2.26 \%)$ \\
\hline Total & 173 & 6749 & 144 & 6404 & $6273(97.95 \%)$ & $131(2.05 \%)$ & 107 & 689 & $677(98.26 \%)$ & $12(1.74 \%)$ \\
\hline
\end{tabular}

Total $=$ number of Canchim animals born after 1953; Available DNA = number of Canchim animals with available DNA; Alive in December $2007=$ number of Canchim animals alive in the herd in December 2007; $N=$ number of founder females; Desc. $=$ number of descendants.

The old lineage of Canchim was constituted by crossing 71 founder Zebu females with Charolais bulls. These females were of three breeds: Indubrasil $(\mathrm{N}=62)$, Guzerat $(\mathrm{N}=3)$, and Nellore $(\mathrm{N}=6)$. DNA samples were only available from matrilineal descendants of $46 \mathrm{fe}$ males (43 Indubrasil, 1 Guzerat, and 2 Nellore). To form the new lineage of the Canchim breed after 1986, only Nellore $(\mathrm{N}=102)$ females were employed, of which 98 maternal lines were available for laboratory analysis. Thus, among the 173 founder Zebu females that contributed to the formation of the Canchim breed of the Southeast-Embrapa Cattle herd, 144 females and their 6404 offspring were mitotyped (Table 1).

Only homoplasmy of mtDNA genotype was observed; no simultaneous amplification of $B$. taurus and $B$. indicus mtDNA was observed in any of the animals (Figure 1). Among the 144 founder females, only three (1 Indubrasil and 2 Nellore) had mtDNA of $B$. indicus origin; there were 131 Canchim cattle with $B$. indicus mtDNA (2.05\%) and 6273 with $B$. taurus mtDNA (97.95\%) in this herd (Table 1).

The B. taurus mtDNA frequency of live animals in the herd in December $2007(\mathrm{~N}=$ 689 ) was over $98 \%$; there was less than $2 \%$ Bos indicus mtDNA in the population (Table 1). The old, new and crossbred lineages also had $98-99 \%$ B. taurus mtDNA (Table 2). 


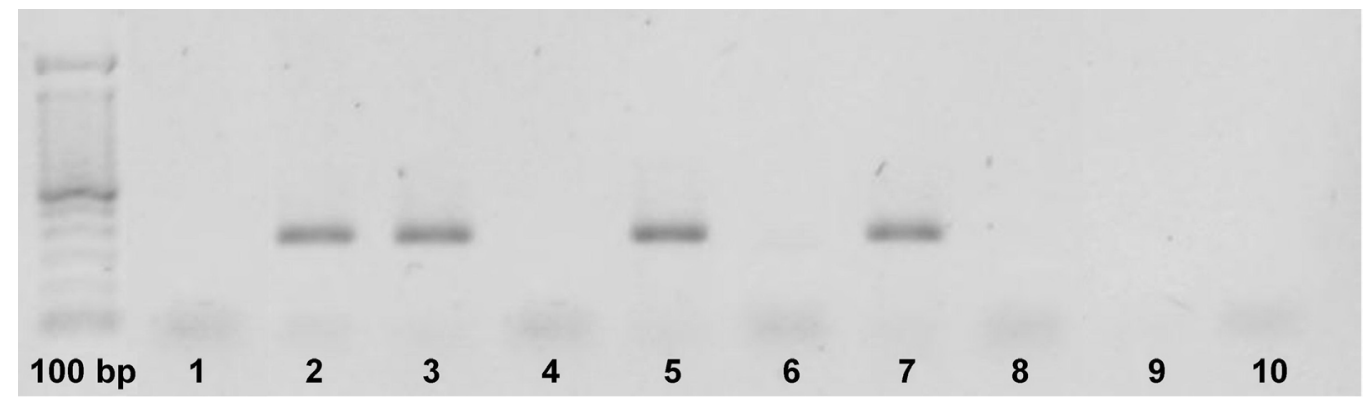

Figure 1. Mitochondrial DNA genotyping in the Canchim beef cattle breed. Each animal sample was submitted to two polymerase chain reaction (PCR) amplifications, which were sequentially numbered. Odd numbers correspond to a Bos taurus specific fragment, and even numbers to B. indicus. 100 bp: 100-bp molecular weight ladder. Lanes 1-2 $=$ One animal with $B$. indicus mtDNA; lanes 3-4, 5-6, and 7-8 = three animals with B. taurus mtDNA; lanes 9-10= PCR control without DNA.

Table 2. Mitochondrial genotype (mtDNA) origin (Bos taurus or Bos indicus) in three lineages of the Canchim beef cattle breed from Southeast-Embrapa Cattle herd in December 2007.

\begin{tabular}{lcc}
\hline Lineage & B. taurus mtDNA N $(\%)$ & B. indicus mtDNA N $(\%)$ \\
\hline Old & $172(98.85 \%)$ & $1(1.15 \%)$ \\
New & $308(98.1 \%)$ & $6(1.9 \%)$ \\
Crossbred & $196(98.0 \%)$ & $4(2.0 \%)$ \\
Total & $677(98.26 \%)$ & $12(1.74 \%)$ \\
\hline
\end{tabular}

\section{DISCUSSION}

The Canchim beef cattle have been developed at the Southeast-Embrapa Cattle station since the 1940s. The first descendant of the old lineage was produced in 1953 based on rotational crossing of Charolais bulls to Zebu females of the Indubrasil $(\mathrm{N}=127)$, Guzerat ( $\mathrm{N}$ $=9)$, and Nellore $(\mathrm{N}=9)$ breeds (Alencar, 1988). Among the old lineage animals, we observed that only 71 (62 Indubrasil, 3 Guzerat, and 6 Nellore) of the 145 founder females generated Canchim descendants.

Considering all lineages: old, new (produced after 1986), and crossbred (obtained after 1998 by reciprocal crossing between old and new lineages), the 173 founder Zebu (62 Indubrasil, 3 Guzerat, and 108 Nellore) females produced 6749 Canchim descendants. However, genetic material for mitochondrial genotype characterization was only available from descendants of 144 founder females (43 Indubrasil, 1 Guzerat, and 100 Nellore); consequently, it was possible to infer it for 6404 individuals.

In December 2007, there were 689 live animals in the herd, which were descendants of 107 females. Only $61.5 \%$ (107/173) of the founder females were still represented in the Canchim herd 55 years after its formation, with a $0.7 \%$ mean elimination rate per year, possibly due to the absence of female descendants in some maternal lines, since male descendants do not transfer mtDNA to the next generation.

We used a polymorphism in the mitochondrial $16 \mathrm{~S}$ (rRNA) gene to identify the 
mtDNA origin as B. taurus or B. indicus by allele-specific PCR (Ferreira et al., 2007). Though more modern assays are available, non-quantitative PCR is still employed as a highly sensitive technique for mtDNA genotyping (Wai et al., 2008).

As only three among the 144 founder females had B. indicus mtDNA, its frequency was very low among the descendants (just over 2\%), the live animals in December 2007 (less than $2 \%$ ) and the three lineages (old, new, and crossbred; $1-2 \%$ ). The high prevalence of $B$. taurus mtDNA in the Canchim breed formed by founder females of Zebu origin confirms the historical data that Brazilian Zebu cows were obtained by backcrossing local (B. taurus mtDNA) females with Zebu males. Since mtDNA is exclusively inherited by the maternal line (Birky Jr., 1994), the Zebu (Indubrasil, Guzerat, and Nellore) founder females of the Canchim breed have mtDNA of B. taurus origin, as observed for most animals of Nellore, Gyr, and Brahman breeds (Meirelles et al., 1999) and for some Guzerat animals (Paneto et al., 2008).

There are several reports of influence of mtDNA polymorphism on production traits in cattle, including the 16S (rRNA) gene that we evaluated here (Mannen et al., 2003). Unfortunately, due to the low B. indicus mtDNA frequency in the Canchim breed of this herd, statistical analyses could not be performed to associate mtDNA genotype origin (B. taurus or B. indicus) with production traits.

Characterization of mtDNA genotype is used to study mitochondrial segregation after production of individuals with heteroplasmic mtDNA (Meirelles and Smith, 1997). This information can direct animal selection to the mitochondrial genotype of interest. However, to assess the effects of mtDNA origin on production traits in the Canchim breed of the SoutheastEmbrapa Cattle herd, it would be necessary to develop a research population with a higher frequency of $B$. indicus mtDNA.

We conclude that the Canchim cattle breed of the Southeast-Embrapa Cattle herd was formed by founder females of Zebu breeds (Indubrasil, Guzerat, and Nellore), harboring mainly mtDNA of Bos taurus origin ( $>97.95 \%$ ), independent of lineage (old, new, and crossbred). Since mtDNA may play a role in animal production traits, these results may be useful for developing strategies for selecting new Canchim beef cattle lineages for further studies.

\section{ACKNOWLEDGMENTS}

Research supported by Southeast-Embrapa Cattle.

\section{REFERENCES}

Alencar MM (1988). Bovino - Raça Canchim: Origem e Desenvolvimento. 1st edn. Embrapa-DPU, Brasília.

Alencar MM (1997). Utilização do Touro Canchim em Cruzamento Comercial. In: Anais da $3^{\text {a }}$ Convenção Nacional da Raça Canchim Embrapa Pecuária Sudeste/São Paulo: ABCCAN, São Carlos, 19-33.

Andrade PC, Grossi DA, Paz CC, Alencar MM, et al. (2008). Association of an insulin-like growth factor 1 gene microsatellite with phenotypic variation and estimated breeding values of growth traits in Canchim cattle. Anim. Genet. 39: 480-485.

Barbosa PF (2000). O Canchim na Embrapa Pecuária Sudeste. In: Anais da $4^{\text {a }}$ Convenção Nacional da Raça Canchim Embrapa Pecuária Sudeste, São Carlos, 55-68.

Birky CW Jr (1994). Relaxed and stringent genomes: why cytoplasmic genes don't obey Mendel's laws. J. Heredity 85: 355-365.

Boettcher PJ, Kuhn MT and Freeman AE (1996). Impacts of cytoplasmic inheritance on genetic evaluations. J. Dairy Sci. 79: 663-675. 
Ferreira CR, Meirelles FV, Yamazaki W, Chiaratti MR, et al. (2007). The kinetics of donor cell mtDNA in embryonic and somatic donor cell-derived bovine embryos. Cloning Stem Cells 9: 618-629.

Larsson NG and Clayton DA (1995). Molecular genetic aspects of human mitochondrial disorders. Annu. Rev. Genet. 29: 151-178.

Machado MBB, Alencar MM, Pereira AP, Oliveira HN, et al. (2003). QTL affecting body weight in a candidate region of cattle chromosome 5. Genet. Mol. Biol. 26: 259-265.

Mannen H, Kojima T, Oyama K, Mukai F, et al. (1998). Effect of mitochondrial DNA variation on carcass traits of Japanese Black cattle. J. Anim. Sci. 76: 36-41.

Mannen H, Morimoto ML, Oyamat K, Mukai F, et al. (2003). Identification of mitochondrial DNA substitutions related to meat quality in Japanese Black cattle. J. Anim. Sci. 81: 68-73.

Meirelles SL (2007). Características de Carcaça de Bovinos da raça Canchim - Estimativas de Parâmetros Genéticos e Associação com Marcadores Moleculares. Doctoral thesis, Faculdade de Ciências Agrárias e Veterinárias, UNESP, Jaboticabal.

Meirelles FV and Smith LC (1997). Mitochondrial genotype segregation in a mouse heteroplasmic lineage produced by embryonic karyoplast transplantation. Genetics 145: 445-451.

Meirelles FV, Rosa AJM, Lôbo RB, Garcia JM, et al. (1999). Is the American Zebu really Bos indicus? Genet. Mol. Biol. 22: 543-546.

Meirelles FV, Bordignon V, Watanabe Y, Watanabe M, et al. (2001). Complete replacement of the mitochondrial genotype in a Bos indicus calf reconstructed by nuclear transfer to a Bos taurus oocyte. Genetics 158: 351-356.

Paneto JC, Ferraz JB, Balieiro JC, Bittar JF, et al. (2008). Bos indicus or Bos taurus mitochondrial DNA - comparison of productive and reproductive breeding values in a Guzerat dairy herd. Genet. Mol. Res. 7: 592-602.

Pereira AP, Alencar MM, Oliveira HN and Regitano LCA (2005). Association of $G H$ and $I G F-1$ polymorphisms with growth traits in a synthetic beef cattle breed. Genet. Mol. Biol. 28: 230-236.

Regitano LCA (2001). Extração de DNA para Aplicação em Reação de Cadeia da Polimerase. In: Biologia Molecular Aplicada à Produção Animal (Regitano LCA and Coutinho LL, eds.). 1st edn. Embrapa Informação Tecnológica, Brasília, 179-186.

Regitano LCA, Azevedo JL, Vencovsky R, Packer IU, et al. (1999). Selection for breed-specific growth hormone and IGF-I alleles in a synthetic beef cattle cross, Cachim. Genet. Mol. Biol. 22: 531-537.

Schutz MM, Freeman AE, Lindberg GL, Koehler CM, et al. (1994). The effect of mitochondrial DNA on milk production and health of dairy cattle. Livest. Prod. Sci. 37: 283-295.

Sutarno CG, Cummins JM, Greeff J and Lymbery AJ (2002). Mitochondrial DNA polymorphisms and fertility in beef cattle. Theriogenology 57: 1603-1610.

Tamassia M, Nuttinck F, May-Panloup P, Reynier P, et al. (2004). In vitro embryo production efficiency in cattle and its association with oocyte adenosine triphosphate content, quantity of mitochondrial DNA, and mitochondrial DNA haplogroup. Biol. Reprod. 71: 697-704.

Vianna AT, Pimentel-Gomes F and Santiago M (1978). Formação do Gado Canchim pelo Cruzamento Charolês-Zebu. 2nd edn. Nobel, São Paulo.

Wai T, Teoli D and Shoubridge EA (2008). The mitochondrial DNA genetic bottleneck results from replication of a subpopulation of genomes. Nat. Genet. 40: 1484-1488. 